\title{
CELLULOSE ACETATE/COPPER (II) OXIDE NANOCOMPOSITE FOR SELECTIVE DETECTION AND EXTRACTION OF LEAD (II) IONS
}

\author{
KHALID ALAMRY, ${ }^{*}$ SHER KHAN, ${ }^{* * *}$ ELHAM BIFARI ${ }^{*}$ and ABDULLAH ASIRI ${ }^{* * * *}$ \\ "Chemistry Department, Faculty of Science, King Abdulaziz University, \\ P. O. Box 80203, Jeddah 21589, Saudi Arabia \\ ** Center of Excellence for Advanced Materials Research (CEAMR), King Abdulaziz University, \\ P. O. Box 80203, Jeddah 21589, Saudi Arabia \\ \Corresponding author: K. A. Alamry, kaalamri@kau.edu.sa
}

Received September 15, 2020

\begin{abstract}
Nanocomposites (NCs) based on cellulose acetate (CA) were prepared by dispersing copper (II) oxide $(\mathrm{CuO})$ nanofillers in the cellulose acetate matrix. Nanocomposites were structurally examined by different spectroscopic techniques. The $\mathrm{CA} / \mathrm{CuO} \mathrm{NCs}$ were immobilized on a silver electrode (AgE) to investigate its chemical sensing behavior toward lead ions by I-V (current $v s$. voltage) technique. The calibration curve showed good electrical response toward $\mathrm{Pb}^{+2}$ with linearity up to $100 \mu \mathrm{M}$. The linear range exhibited good sensitivity $\left(213.43 \mu \mathrm{A} \cdot \mathrm{cm}^{-2} \cdot \mathrm{mM}^{-1}\right)$. The electrical performance showed an optimum response at $\mathrm{pH} 6$ and good selectivity toward $\mathrm{Pb}^{+2}$, compared to the interference of other metal ions. Further, the selectivity of NCs toward different metal ions, including $\mathrm{Zn}^{2+}, \mathrm{Ni}^{2+}, \mathrm{Pb}^{2+}$, $\mathrm{Mn}^{2+}, \mathrm{Sr}^{3+}, \mathrm{Al}^{3+}, \mathrm{Fe}^{3+}$ and $\mathrm{Ce}^{3+}$, was investigated by inductively coupled plasma optical emission spectroscopy. $\mathrm{CA} / \mathrm{CuO}(3 \% \mathrm{w} / \mathrm{w})$ displayed higher uptake capacity for $\mathrm{Pb}^{2+}$ with $\mathrm{K}_{\mathrm{d}}$ of $344170 \mathrm{~mL} / \mathrm{g}$. These data revealed that $\mathrm{CA} / \mathrm{CuO} \mathrm{NCs}$ exhibit high sensitivity and selectivity toward detection and extraction of lead ions and could be used for the efficient removal of $\mathrm{Pb}^{2}$.
\end{abstract}

Keywords: cellulose acetate, $\mathrm{CuO}$, nanocomposite, sensor, lead ion, detection, extraction, water treatment

\section{INTRODUCTION}

Environmental contamination with lead $(\mathrm{Pb})$ has become a growing issue because of the serious toxic effects of $\mathrm{Pb}$ on human health. Several reports claim that exposure to lead, even at trace levels, may cause some serious damaging, such as irritability, muscle paralysis, nerve disorders and memory loss. Therefore, the identification of lead at trace levels in the environment and its extraction have become a topic of major interest. ${ }^{1-6}$

Several techniques have been successfully used for determining trace heavy metals. ${ }^{7-10}$ However, due to the simplicity, low cost, fast response and high sensitivity and specificity, the electrochemical techniques have been established as promising methods for the determination of heavy metal ions. Polymer modified electrodes have been recently used in electrochemical applications since the characteristic properties of the polymer used, such as its catalytic, permeability, preconcentration and transport properties, helped to further promote the performance of the electrochemical analysis. ${ }^{11-13}$ Modified electrodes in the electrochemical analysis of trace heavy metals can bring out several advantages, such as an improvement in the sensitivity and selectivity of trace analytes, as well as reduction of contaminants and competing ligands. ${ }^{5,14}$ Thus, to further improve the properties of these polymers, and subsequently boost up electrochemical analysis, several advances have been made in nanotechnology by the development of polymer nanocomposites. ${ }^{15,16}$ Among the nanofillers used, metal oxide nanomaterials have been considered as great candidates in chemical sensing and biosensing due to their thermal stability, chemical inertness with chemicals and biomolecules, and low temperature operation, ${ }^{17}$ in addition to the possibility of manipulating their surfaces to make them suitable enough for the proposed application. ${ }^{18}$

The field of material science and nanotechnology has motivated scientists all over the world to advance materials with innovative 
properties that cannot be encountered in conventional materials. ${ }^{19-22}$ The development of nanocomposites has increased markedly in recent years due to the great potential associated with this new generation of extraordinary materials. ${ }^{23-}$ 27 Nanocomposites research embraces a wide spectrum of applications, such as data storage, electronics and computing, communications, transportation, health and medicine, aerospace and sports materials, energy, environmental, and national defence applications. ${ }^{28-31}$

Cellulose acetate (CA) is an important biobased polymer that has been used in a broad range of applications. ${ }^{32-34}$ Even though, CA has played a significant role in various applications, the incorporation of various nanofillers, such as CNT, clays, metal oxides, nanoparticles etc., can lead to developing a CA polymer with a suitable property profile for countless applications and utilization possibilities. ${ }^{35-37}$ According to literature, several studies have embraced the development of cellulose acetate based nanocomposites in areas including plastics and packaging, membranes and separation media, water treatment and sensing. For instance, enhancing the mechanical, thermal, photocatalytic, permeability, sorption and antifouling properties of cellulose acetate based nanocomposites has extended its effective use in dechlorination and removal of heavy metals, dyes and other organic compounds. ${ }^{38-47}$

In this project, $\mathrm{CA} / \mathrm{CuO}$ nanocomposites were prepared by a simple blending method and were used to investigate their selectivity toward metal ion uptake. Considering that $\mathrm{CuO}$ nanomaterials have good electrical conductivity, ${ }^{48}$ high stability and high catalytic activity, ${ }^{49}$ the $\mathrm{CA} / \mathrm{CuO}$ nanocomposite was developed and studied with regard to its sensing performance toward $\mathrm{Pb}$ (II) ion detection and extraction.

\section{EXPERIMENTAL}

\section{Reagents and materials}

All chemicals and reagents were purchased from Sigma Aldrich and used directly without further treatments. Deionized water was used throughout the experiment.

\section{Synthesis of nanomaterials}

$\mathrm{CuO}$ nanomaterials were synthesized from a $0.1 \mathrm{M}$ aqueous solution of its precursor - copper nitrate hexahydrate $\left(\mathrm{Cu}\left(\mathrm{NO}_{3}\right)_{2} \cdot 6 \mathrm{H}_{2} \mathrm{O}\right)$ and $5 \mathrm{wt} \%$ of carbon black (CB). Carbon black (5 wt \%) was dispersed in the aqueous solution of $(0.1 \mathrm{M}) \mathrm{Cu}\left(\mathrm{NO}_{3}\right)_{2} \cdot 6 \mathrm{H}_{2} \mathrm{O}$ and an adequate amount of $(0.5 \mathrm{M})$ sodium hydroxide $(\mathrm{NaOH})$ was added dropwise to the mixture with constant stirring until the $\mathrm{pH}$ of the solution rose above 10. The stirring process was maintained for $12 \mathrm{~h}$ at 80 ${ }^{\circ} \mathrm{C}$, and then the product was allowed to cool down to room temperature. The obtained $\mathrm{CuO}$ precipitation was washed several times with deionized water to remove any impurities. ${ }^{48}$

\section{Synthesis of nanocomposite}

In this study, different compositions of cellulose acetate/copper (II) oxide $(\mathrm{CA} / \mathrm{CuO})$ nanocomposite films, with $\mathrm{CA} / \mathrm{CuO}$ weight ratios of 100/0, 100/1, $100 / 3,100 / 5$ and 100/10, were prepared by the blending method. These NCs were named as CA, $\mathrm{CA} / \mathrm{CuO}(1 \%), \mathrm{CA} / \mathrm{CuO}(3 \%), \mathrm{CA} / \mathrm{CuO}(5 \%)$ and $\mathrm{CA} / \mathrm{CuO}(10 \%) .1 \mathrm{~g}$ of cellulose acetate was dissolved in an adequate amount of acetone under magnetic stirring at ambient temperature. For each series, the required amount of $\mathrm{CuO}$ nanomaterials was dispersed separately in $10 \mathrm{~mL}$ of ethanol and magnetically stirred at $40{ }^{\circ} \mathrm{C}$ for $1 \mathrm{~h}$ in order to prevent coagulation and precipitation. The dispersed solution of MO/ethanol was then added dropwise to the $\mathrm{CA}$ /acetone solution and continuous stirring was performed for $5 \mathrm{~h}$ at $60{ }^{\circ} \mathrm{C}$. Later on, the suspension was poured on a Petri dish and left to dry at room temperature. After drying, the film was removed and stored in a plastic bag until further studies.

\section{Characterization}

The $\mathrm{CuO}$ nanomaterial and $\mathrm{NCs}$ were structurally characterized by the following techniques. X-ray diffraction patterns (XRD) were taken with a computer controlled X'Pert Explorer PANalytical diffractometer. FT-IR spectra were recorded in the range from 400 to $4000 \mathrm{~cm}^{-1}$ on a PerkinElmer (spectrum 100) FT-IR spectrometer. The thermal behavior of the prepared nanocomposites was analyzed by a Thermo Scientific TGA in nitrogen atmosphere, at a heating rate of 10 ${ }^{\circ} \mathrm{C} / \mathrm{min}$ from 23 to $1000{ }^{\circ} \mathrm{C}$. Millipore-Q water purification was employed to produce deionized water of $18.2 \mathrm{M} \Omega . \mathrm{cm}$ at $25{ }^{\circ} \mathrm{C}$, TOC $<5 \mathrm{ppb}$. The I-V technique was employed for metal ion detection by using a Kethley Electrometer (Kethley 2400, Electrometer, USA). ICP-OES measurements were acquired by the use of a PerkinElmer ICP-OES model (Optima 7000 DV, USA). The ICP-OES instrument was optimized daily before measurement and ran as recommended by the manufacturers.

\section{Fabrication of chemical sensor and selective detection of lead ions}

The $\mathrm{CA} / \mathrm{CuO}$ nanocomposite was used as a thin film for coating the surface of a silver electrode, using nafion as a binder and dried at $60.0{ }^{\circ} \mathrm{C}$ for 12 hours. The sensing ability of the composite modified $\mathrm{AgE}$ was evaluated using different metal ions. A twoelectrode system was used for sensing metal ions, i.e. $\mathrm{Ag} / \mathrm{AgCl}$ as a reference electrode and the composite modified AgE (with internal surface area of $0.021 \mathrm{~cm}^{2}$ ) 
as a working electrode. The current response was measured from 0 to 1.0 volts. The amount of acetate buffer solution was kept constant at $20.0 \mathrm{~mL}$ for all the measurements.

\section{Metal ion uptake experiment}

For studying the selectivity of the NC phase toward metal ions, standard solutions of $30 \mathrm{mg} \mathrm{L}^{-1}$ of each $\mathrm{Zn}^{2+}, \mathrm{Ni}^{2+}, \mathrm{Pb}^{2+}, \mathrm{Mn}^{2+}, \mathrm{Sr}^{3+}, \mathrm{Al}^{3+}, \mathrm{Fe}^{3+}$ and $\mathrm{Ce}^{3+}$ ions were prepared in $0.01 \mathrm{M}$ potassium nitrate diluted in distilled deionized water. $35 \mathrm{~mL}$ of each standard solution was individually mixed with $5.2 \mathrm{mg}$ of $\mathrm{CA} / \mathrm{CuO}(5 \% \mathrm{w} / \mathrm{w})$ nanocomposite. All the mixtures were mechanically shaken for $24 \mathrm{~h}$ at $25^{\circ} \mathrm{C}$. After $24 \mathrm{~h}$ of equilibration, the suspensions were filtered using Whatman 42 filter paper, and the filtrate was analyzed for the concentration of metal ions using inductively coupled plasma optical emission spectrometry (ICPOES). ${ }^{50,51}$ The distribution coefficient $\left(\mathrm{K}_{\mathrm{d}}\right)$ values were determined by using Equation 1:

$K_{d}=\left(\frac{C_{e}-C_{\varepsilon}}{C_{\varepsilon}}\right) \cdot\left(\frac{V}{m}\right)$

where $\mathrm{C}_{\mathrm{o}}$ and $\mathrm{C}_{\mathrm{e}}$ are the initial and final concentrations before and after filtration with the nanocomposite, respectively, $\mathrm{V}$ refers to the volume $(\mathrm{mL})$ and $\mathrm{m}$ is the weight of CA and nanocomposite $(\mathrm{g}) .^{50}$

The metal ions that obtained the highest $\mathrm{K}_{\mathrm{d}}$ values for each system were further investigated in the same batch process, with different nanocomposite fractures.

\section{RESULTS AND DISCUSSION \\ Physiochemical characterization of $\mathrm{CA} / \mathrm{CuO}$ nanocomposites}

The chemical structure and crystallinity of $\mathrm{CuO}$ and $\mathrm{CA} / \mathrm{CuO}$ nanocomposites were examined by typical powder X-ray diffraction and

A.

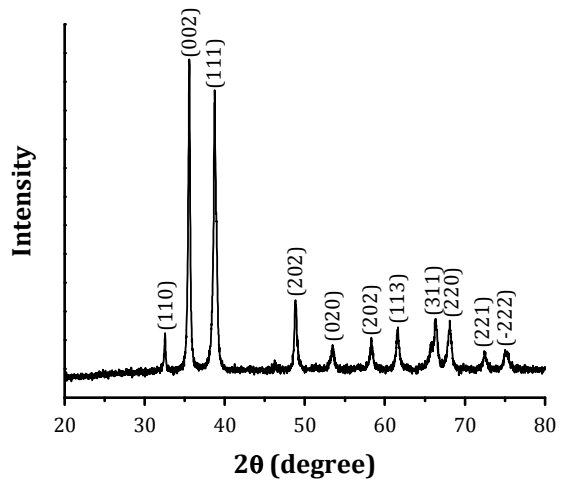

the graph is depicted in Figure 1. The general feature of the XRD patterns of the $\mathrm{CuO}$ nanomaterial exhibits the occurrence of only strong and sharp diffraction peaks at $2 \theta$ of 32.6, 35.5, 38.8, 48.8, 53.4, 58.3, 61.6, 66.3, 68.1, 72.4 and $75.1 \AA$, which could be assigned to the (110), (002), (111), (202), (020), (202), (113), (311), (220), (221) and (-222) planes of the monoclinic $\mathrm{CuO}$ structure with space group $\mathrm{C} 2 / \mathrm{c}$., respectively. ${ }^{52,53}$ The absence of halos and other impure diffraction peaks within the detection limit of the X-ray diffraction confirms the phase purity and the presence of a highly crystalline structure of the synthesized $\mathrm{CuO}$ nanomaterial.

The X-ray diffraction pattern (XRD) of the $\mathrm{CA} / \mathrm{CuO}$ nanocomposites shows the presence of a characteristic broad halo peak in the range of 15$30 \AA$, coming from the amorphous nature of CA, in addition to several sharp crystalline peaks at 35.7, 39.1, 49.0, 58.8, 61.6, 66.4, 68.1, 72.6 and $75.2 \AA$, which represent the presence of the $\mathrm{CuO}$ nanomaterial in the nanocomposite. The $\mathrm{CuO}$ crystalline peaks show a gradual increase in intensity with the increase in $\mathrm{CuO}$ concentration. The alteration in the strength of the peaks intensity of some of the phases from that observed in the nanomaterials may be caused by the strong interaction between $\mathrm{CuO}$ and $\mathrm{CA}$. Thus, the data obtained from XRD patterns suggest the successful formation of nanocomposites from the two phases, cellulose acetate and different concentrations of $\mathrm{CuO}$ nanomaterials. ${ }^{48}$

B.

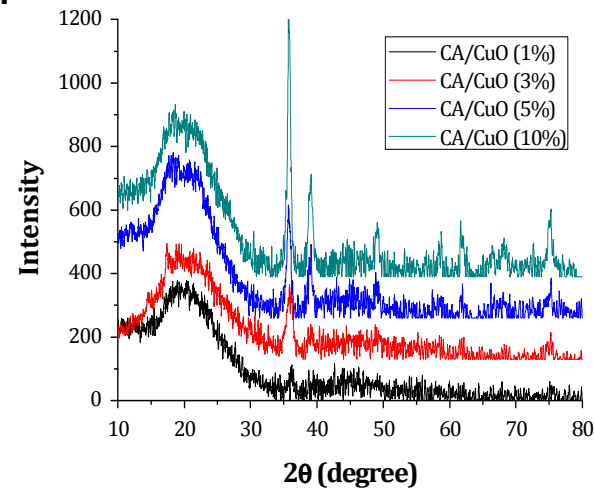

Figure 1: X-ray diffraction (XRD) patterns of (A) polymer composite of $\mathrm{CuO}$ and $\mathrm{CA} / \mathrm{CuO}$ nanocomposite, (B) $\mathrm{CA}$ loaded with different percentage of $\mathrm{CuO}$ 


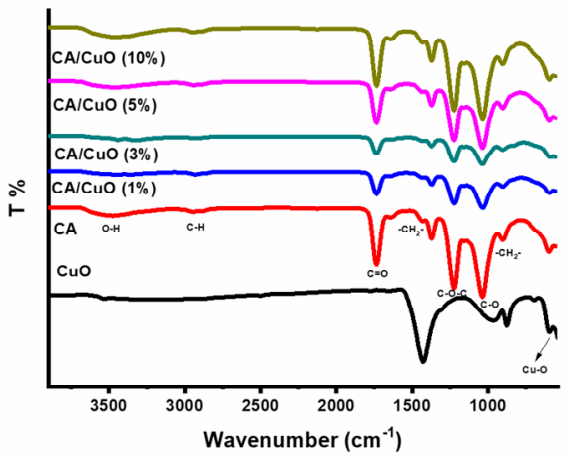

Figure 2: Typical FT-IR spectra of $\mathrm{CA}, \mathrm{CuO}$ and $\mathrm{CA} / \mathrm{CuO} \mathrm{NCs}$

A.

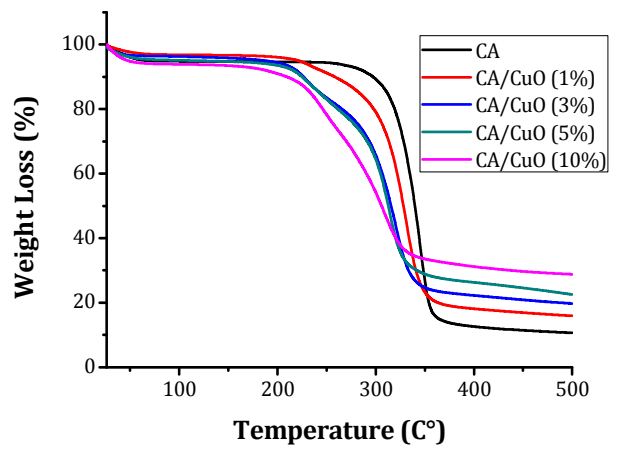

B.

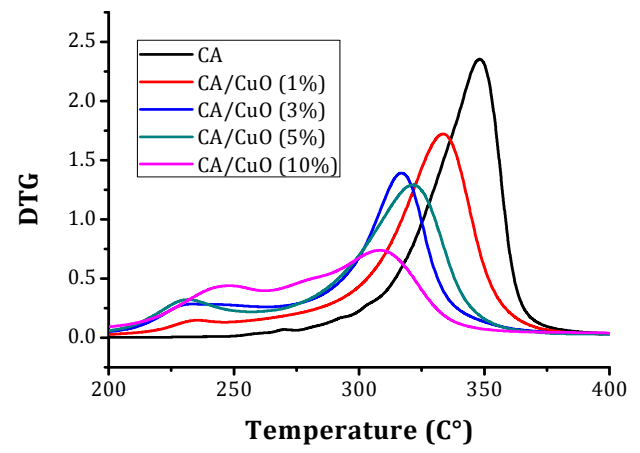

Figure 3: A) TGA curves of pure $\mathrm{CA}$ and $\mathrm{CA} / \mathrm{CuO} \mathrm{NCs}, \mathrm{B})$ DTA curves of pure $\mathrm{CA}$ and $\mathrm{CA} / \mathrm{CuO} \mathrm{NCs}$

For studying the chemical structure and composition of the nanocomposites, the FT-IR spectra of $\mathrm{CA}, \mathrm{CuO}$ and different compositions of $\mathrm{CA} / \mathrm{CuO}$ nanocomposites were recorded and presented in Figure 2. As mentioned earlier, the FT-IR spectrum of CA demonstrated absorption bands at $3470,2800-2900,1750,1437,1380$, 1233,1047 and $900 \mathrm{~cm}^{-1}$, which correspond to O$\mathrm{H}, \mathrm{C}-\mathrm{H}, \mathrm{C}=\mathrm{O},-\mathrm{CH}_{2^{-}}, \mathrm{C}-\mathrm{O}-\mathrm{C}$ and $\mathrm{C}-\mathrm{O}$ stretching vibration. $\mathrm{CuO}$ nanomaterials revealed bands at 400-600, 1430 and $3533 \mathrm{~cm}^{-1}$, which are also depicted in Figure 2. The characteristic absorption bands at $500-600 \mathrm{~cm}^{-1}$ are responsible for the metal oxide $(\mathrm{Cu}-\mathrm{O})$ stretching vibration. The absorption bands at 3533 and $1430 \mathrm{~cm}^{-1}$ are assigned to the stretching and bending vibrational modes of absorbed water from surroundings. ${ }^{48}$ The peaks of $\mathrm{CA}$ and $\mathrm{CuO}$ nanomaterials were present in the spectra of each nanocomposite, indicating the formation of $\mathrm{NCs}^{21-24}$

The thermal stability of the $\mathrm{CA} / \mathrm{CuO}$ nanocomposites was evaluated by thermogravimetric analysis (TGA) and differential thermal analysis (DTA). The presence of $\mathrm{CuO}$ nanomaterials within $\mathrm{CA}$ films reduces the thermal stability of $\mathrm{CA}$ by the addition of $\mathrm{CuO}$, from $348{ }^{\circ} \mathrm{C}$ for $\mathrm{CA}$ to $334 \sim 308{ }^{\circ} \mathrm{C}$ for
NCs, without changing the thermal degradation behavior of the CA films. The TGA and DTA curves exhibit similar trends to that of pure CA: ${ }^{54-}$ 57 dehydration, fragmentation, and finally carbonization, regardless of the $\mathrm{CuO}$ content (Fig. 3).

\section{Metal ion detection and extraction Lead ion detection}

The $\mathrm{CA} / \mathrm{CuO}$ nanocomposite was utilized for the selective detection of $\mathrm{Pb}^{+2}$ in aqueous media in order to study its chemical sensing properties toward this metal ion. The $\mathrm{CA} / \mathrm{CuO}$ coated silver electrode was used as a working electrode for the detection of $\mathrm{Pb}^{+2}$. The fabricated working electrode was used to measure the electrical response toward the detection of $\mathrm{Pb}^{+2}$, which is shown in Figure 4.

The I-V curves for the silver electrode without coating (without $\mathrm{CA} / \mathrm{CuO}$ ) and after coating (with $\mathrm{CA} / \mathrm{CuO}$ ) were measured and shown in Figure 5. The composite coated silver electrode illustrates high current response, in contrast to the naked silver electrode, which is attributed to its metal ion sensing property originating from the NC.

Figure 5 also illustrates the electrical response of the working electrode without metal ion and 
with $10.0 \mu \mathrm{L}$ of $\mathrm{Pb}^{+2}$ ion in $20 \mathrm{~mL}$ of buffer solution $(\mathrm{pH}=6.0)$. It is observed from Figure 5 that by adding the target chemical, the working electrode demonstrates a noteworthy enhancement in electrical current, which reveals the sensitivity of the working electrode toward $\mathrm{Pb}^{+2}$. Consequently, by injection of the lead ion, the augmentation in the electrical response shows that the working electrode exhibits a fast and sensitive response to the target metal ion, which might be due to strong binding of the lead ion to the nanocomposite.

The influence of lead ion concentration on the electrical reaction of the working electrode was examined by the subsequent addition of lead ion into $20 \mathrm{~mL}$ of buffer solution $(\mathrm{pH}=6.0)$. An enhancement of the electrical current with the increase in the lead ion concentration is observed, which indicates that the sensing working electrode was enhanced by the increase in the concentration of the target chemical.
The calibration curve (Fig. 6) was plotted for different concentrations of the target ion. The calibration curve portrays two sensitivity areas; the region at inferior concentrations (physisorption process) is linear up to $100 \mu \mathrm{M}$, with the correlation coefficient $\mathrm{R}^{2}=0.972$. The sensitivity is determined from the slope of the lower concentration section of the calibration curve, which is $213.43 \mu \mathrm{A} \cdot \mathrm{cm}^{-2} \cdot \mathrm{mM}^{-1}$. These results were compared with others reported in the literature, as shown in Table $1 .^{58-60}$ The linear dynamic range is revealed from $10.0 \mu \mathrm{M}$ to 100 $\mu \mathrm{M}$, and the detection limit was estimated, based on the signal to noise ratio $(\mathrm{S} / \mathrm{N})$, to be $0.758 \pm 1.82 \mathrm{mM}$. Above $100 \mu \mathrm{M}$ concentration, the sensor became saturated, due to chemisorption, which could be caused by the lack of free composite sites for further lead ion adsorption. ${ }^{61}$

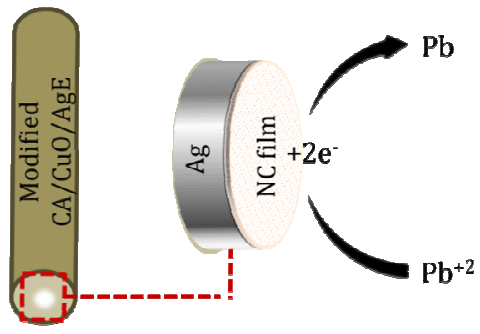

Figure 4: Fabrication of $\mathrm{CA} / \mathrm{CuO}$ nanocomposite on silver electrode and illustration of the electrocatalytic reduction mechanism of lead ion on the composite modified electrode

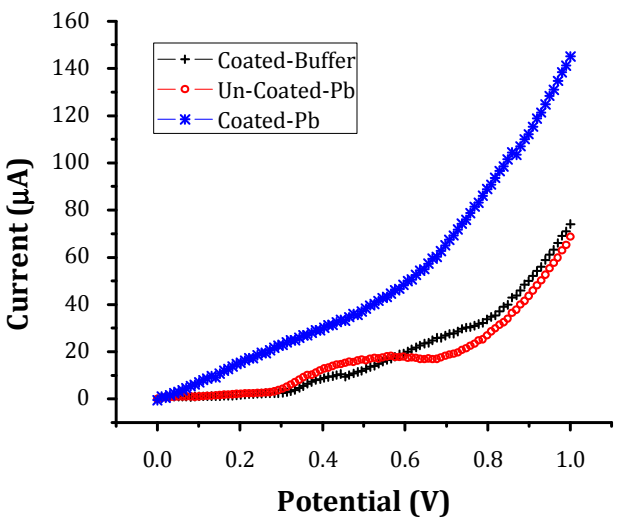

Figure 5: $\mathrm{I}-\mathrm{V}$ characterization of $\mathrm{CA} / \mathrm{CuO} \mathrm{NC}$ for uncoated (in the presence of $10 \mathrm{~mL} \mathrm{~Pb}^{+2}$ ) and coated (in the absence and presence of $10 \mathrm{~mL} \mathrm{~Pb}^{+2}$ ) $\mathrm{AgE}$

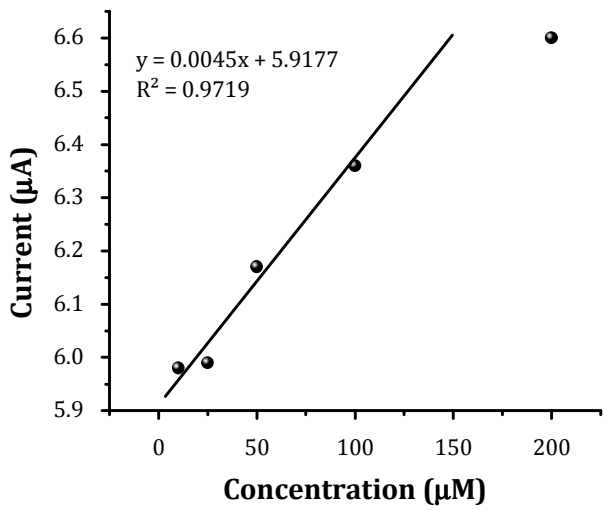

Figure 6: Calibration plot obtained from I-V characterization of $\mathrm{CA} / \mathrm{CuO} / \mathrm{AgE}$ with successive addition of lead ions 
KHALID A. ALAMRY et al.

Table 1

Comparison of the detection limit of $\mathrm{CA} / \mathrm{CuO} \mathrm{NCs}$ with that of other materials employed electrochemically in $\mathrm{Pb}^{2+}$ detection

\begin{tabular}{lccc}
\hline Material & Technique & Sensitivity & Reference \\
\hline $\mathrm{Sb}_{2} \mathrm{O}_{3} / \mathrm{MWCNTs}$ & LSASV & $2.694 \mu \mathrm{AL \mu g}^{-1}$ & 58 \\
$\mathrm{P}(\mathrm{Py} \square \mathrm{co} \square \mathrm{OT}) / \mathrm{CF}$ NCs & $\mathrm{I}-\mathrm{V}$ & $22.39 \mu \mathrm{AM}^{-1} \mathrm{~cm}^{-2}$ & 59 \\
$\mathrm{GO} / \mathrm{MA} \mathrm{NCs}$ & $\mathrm{I}-\mathrm{V}$ & $20.56 \mu \mathrm{AmM}^{-1} \mathrm{~cm}^{-2}$ & 60 \\
$\mathrm{CA} / \mathrm{CuO} \mathrm{NCs}$ & $\mathrm{I}-\mathrm{V}$ & $213.43 \mu \mathrm{A} \cdot \mathrm{cm}^{-2} \cdot \mathrm{mM}^{-1}$ & This study \\
\hline
\end{tabular}

$\mathrm{Sb}_{2} \mathrm{O}_{3}$ /MWCNTs: Multiwall carbon nanotube modified by antimony oxide; P(Py-co-OT)/CF NCs: Poly(pyrrole-co-otoluidine) copolymer and cobalt ferrite; GO/MA NCs: Graphene oxide/methylaniline nanocomposites; LSASV: Square-wave anodic stripping voltammetry

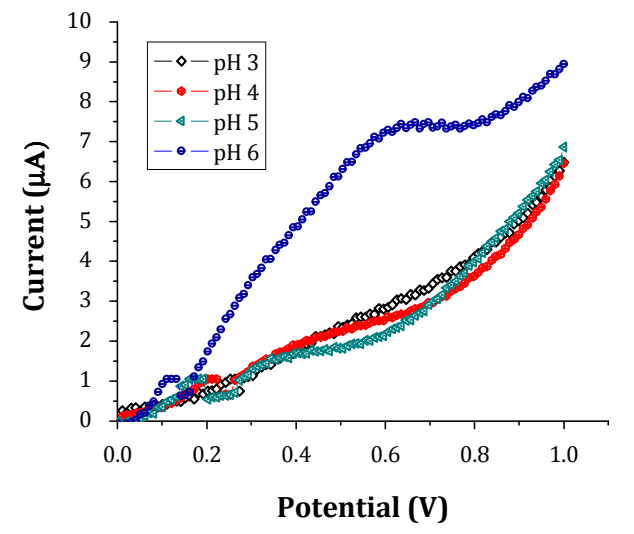

Figure 7: Current response obtained at different $\mathrm{pH}$ on $\mathrm{I}-\mathrm{Vs}$ of $\mathrm{CA} / \mathrm{CuO} / \mathrm{AgE}$ for $\mathrm{Pb}^{+2}$ ions

\section{Influence of $\mathrm{pH}$}

The performance of the sensor was optimized by using different $\mathrm{pH}$ levels (Fig. 7). The presence of the proton $\mathrm{H}^{+}$in the solution plays a crucial part in redox reactions and exerts a significant impact on electrochemical reactions. Therefore, the effect of $\mathrm{pH}$ on the electrochemical reaction was studied by varying the $\mathrm{pH}$ of the solution. It is observed from the figure that the reduction peak current increased with increasing $\mathrm{pH}$ value until it reached the maximum of 6.0. Hence, $\mathrm{pH} 6.0$ was kept as an optimum condition for further analysis. This indicates that the electrical current of the sensor is dependent on the $\mathrm{pH}$ value. ${ }^{62}$

\section{Selectivity of the lead ion sensor}

The selectivity was investigated by using different metal ions as interfering species. Figure 8 shows the electrical response of the sensor toward different metal ions in buffer solution $(\mathrm{pH}$ $=6.0$ ). The electrical response of the sensor is much higher, compared to that to other interfering metal ions, which suggests that the other metal ions have a negligible effect on the lead ion

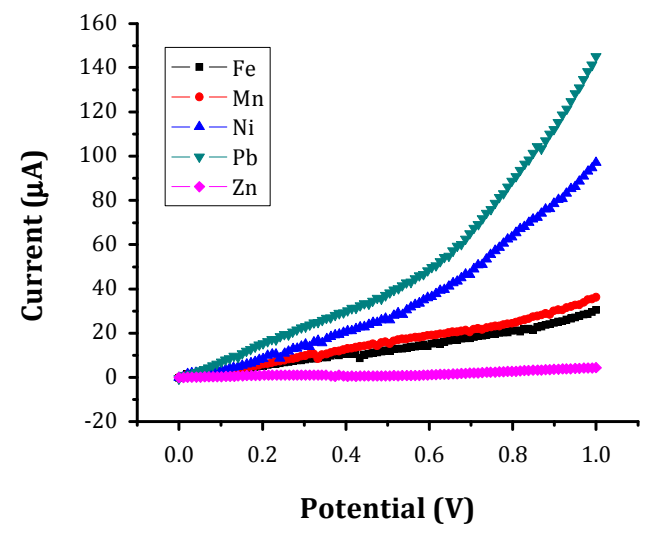

Figure 8: Current response obtained on I-Vs of $\mathrm{CA} / \mathrm{CuO} / \mathrm{AgE}$ for different metal ions

sensing property of the designed sensor, as it is more selective toward the lead ion.

The same composite material was further applied for the selective extraction of lead ions, which is explained in the following section.

Selective extraction of lead ion using nanocomposites

Selectivity studies of $\mathrm{CA}$ and $\mathrm{CA} / \mathrm{CuO}$ nanocomposites toward different metal ions, including $\mathrm{Zn}^{2+}, \mathrm{Pb}^{2+}, \mathrm{Mn}^{2+}, \mathrm{Sr}^{3+}, \mathrm{Al}^{3+}, \mathrm{Fe}^{3+}, \mathrm{Ni}^{2+}$ and $\mathrm{Ce}^{3+}$, were performed by determining the distribution coefficient $\left(K_{d}\right)$ values of all the phases at the optimum $\mathrm{pH}$ value $(\mathrm{pH}$ 6.0) by Equation 1.

The distribution coefficient values of all the metal ions investigated in this study are reported in Figure 9. It can be clearly noticed from the figure that the highest distribution coefficient value was obtained for $\mathrm{Pb}^{2+}$ ions. The selectivity studies revealed that the $\mathrm{CA} / \mathrm{CuO}$ nanocomposites were most selective towards $\mathrm{Pb}^{2+}$ among all the metal ions included in this study. Thus, the results imply that the $\mathrm{CA} / \mathrm{CuO}$ nanocomposites are able to selectively adsorb and bind $\mathrm{Pb}^{2+}$ by either 
electrostatic attraction or the chelating mechanism. $^{51}$

For assessing the uptake capacity, CA and the $\mathrm{CA} / \mathrm{CuO}$ nanocomposites were examined under identical conditions of $\mathrm{pH}$, environment and concentration of $\mathrm{Pb}^{2+}$. The nanocomposite having 3 wt $\%$ of $\mathrm{CuO}$ exhibited the highest uptake capacity for $\mathrm{Pb}^{2+}$, with the highest distribution coefficient of $344170 \mathrm{~mL} \cdot \mathrm{g}^{-1}$ (Fig. 9), which was comparable other literature data, as shown in Table 2. ${ }^{63-65}$ The uptake capacities of $\mathrm{Pb}^{2+}$ for lower and higher concentrations of $\mathrm{CuO}$ were not comparably significant. The decrease in the

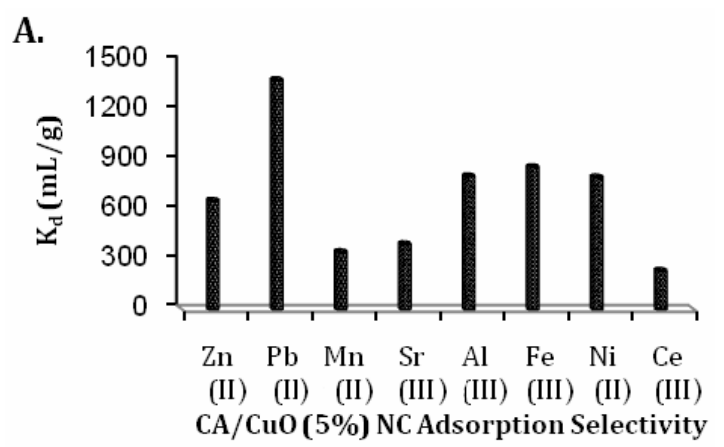

uptake capacity for lower concentration of $\mathrm{CuO}$ might be attributed to being too low to be effective or to synthetic defects, whereas the decrease in the uptake capacity of the $\mathrm{NC}$ with further addition of $\mathrm{CuO}$ might be explained by a reduction of the active surface area of $\mathrm{CuO}$, resulting from the aggregation of the nanomaterials in the $\mathrm{CA}$ matrix. These results also suggest that $3 \% \mathrm{w} / \mathrm{w} \mathrm{CuO}$ is well dispersed in $\mathrm{CA} / \mathrm{CuO}$, but further increase in $\mathrm{wt} \%$ causes a gradual decrease in dispersion and an increase in aggregation.

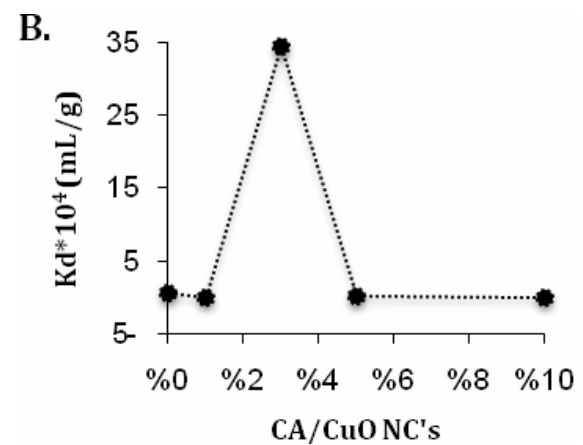

Figure 9: A) Selectivity and $\mathrm{Pb}^{2+}$ uptake capacity of $\mathrm{CA} / \mathrm{CuO}$ NCs $(3 \%)$ among different metal ions, B) Adsorption capacity of $\mathrm{CA} / \mathrm{CuO}(3 \% \mathrm{w} / \mathrm{w})$, displaying the highest uptake aptitude for $\mathrm{Pb}^{2+}$ with the highest $\mathrm{K}_{\mathrm{d}}$ of $344170 \mathrm{~mL} \cdot \mathrm{g}^{-1}$

Table 2

Comparison of uptake capacity and distribution coefficient for $\mathrm{Pb}^{2+}$ adsorption by $\mathrm{CA} / \mathrm{CuO} \mathrm{NCs}$ and other reported materials

\begin{tabular}{lcc}
\hline Material & $\mathrm{K}_{\mathrm{d}}\left(\mathrm{mLg}^{-1}\right)$ & Reference \\
\hline Ca-doped $\mathrm{ZnO}$ nanoparticles & $5.67 \times 10^{5}$ & 63 \\
$\mathrm{CdO}$ codoped $\mathrm{Fe}_{2} \mathrm{O}_{3}$ nanofiber & $1.21 \times 10^{5}$ & 64 \\
$\mathrm{Ni}-\mathrm{ZnO}$ nanoparticles & $5.98 \times 10^{5}$ & 65 \\
$\mathrm{CA} / \mathrm{CuO}$ NCs & 344170 & This study \\
\hline
\end{tabular}

The possible mechanism for adsorption of $\mathrm{Pb}^{2+}$ might be due to strong attraction of $\mathrm{Pb}^{2+}$ to $\mathrm{CA} / \mathrm{CuO}$, which has a large specific surface area, and its surface is covered with $\mathrm{OH}, \mathrm{Cu}-\mathrm{O}-$ and $\mathrm{O}-$, which could be easily charged and combined with $\mathrm{Pb}^{2+} . \mathrm{CuO}$ and other metal oxides have been reported as adsorbents, however, in powder form, these adsorbents are difficult to separate from the solution. To find a simple and inexpensive method for separating adsorbents from the solution, the nanocomposite of $\mathrm{CuO}$ and $\mathrm{CA}$ matrix is a convenient choice. $\mathrm{CA} / \mathrm{CuO}$ has a large specific surface area, and due to the $\mathrm{OH}$, $\mathrm{Cu}-\mathrm{O}-$ and $-\mathrm{O}-$ on its surface, can easily absorb heavy metal ions. The higher $\mathrm{Pb}^{2+}$ concentration resulted in stronger competition among different heavy metal ions, which might be due to a replacement of other metal ions adsorbed on the surface of the $\mathrm{CA} / \mathrm{CuO}$ by $\mathrm{Pb}^{2+}$ and therefore, $\mathrm{Pb}^{2+}$ was more competitive than other metal ions. These different properties of heavy metal ions, such as ionic potential, electronegativity, easy hydroxylation and position in the Irving-Williams series, also made a difference in the removal efficiency of heavy metal ions. The preference of the sorbent for $\mathrm{Pb}^{2+}$ may be because the metal ions have the largest atomic weight and are paramagnetic, and the most electronegative ion has the highest standard reduction potential, as compared to other metal ions. Another reason may be related to the hydration energy and the hydrated ionic radius of heavy metals, and a lower 
hydration energy was easier for the adsorption. ${ }^{66}$ Schematically, the adsorption of $\mathrm{Pb}^{2+}$ onto
$\mathrm{CA} / \mathrm{CuO}$ is shown in Figure 10.

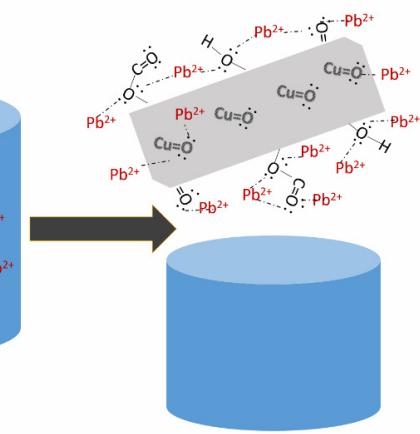

Figure 10: Schematic diagram of $\mathrm{Pb}^{2+}$ adsorption by $\mathrm{CA} / \mathrm{CuO} \mathrm{NCs}$

\section{CONCLUSION}

The synthesized $\mathrm{CA} / \mathrm{CuO}$ nanocomposites were studied in terms of their sensing performance and selectivity toward metal ions. The modified AgE showed good electrical response toward lead ions detection, with linearity $\left(\mathrm{R}^{2}=0.972\right)$ up to $100 \mu \mathrm{M}$. The linear range exhibited a sensitivity of $213.43 \mu \mathrm{A} \cdot \mathrm{cm}^{-2} \cdot \mathrm{mM}^{-1}$ and LOD of $0.758 \pm 1.82 \mathrm{mM}$. The electrical performance showed an optimum response at $\mathrm{pH}$ 6 and good selectivity toward lead ions, regardless of the interference of other metal ions. This was confirmed by the selectivity data. $\mathrm{CA} / \mathrm{CuO}(3 \% \mathrm{w} / \mathrm{w})$ displayed the highest uptake capacity for $\mathrm{Pb}^{2+}$, with the highest $\mathrm{K}_{\mathrm{d}}$ of 344170 $\mathrm{mL} \cdot \mathrm{g}^{-1}$. Additional studies performed by ICPOES confirmed the selectivity of $\mathrm{CA} / \mathrm{CuO}$ toward $\mathrm{Pb}^{2+}$, while $\mathrm{CA} / \mathrm{CuO}(3 \% \mathrm{w} / \mathrm{w})$ showed the highest uptake capacity.

ACKNOWLEDGEMENT: This project was funded by the Center of Excellence for Advanced Materials Research (CEAMR), King Abdulaziz University, Jeddah, under grant no. CEAMR-SG$5-435$.

\section{REFERENCES}

1 X. M. Miao, L. S. Ling and X. T. Shuai, Anal. Biochem. 421, $\quad 582$

(2012), https://doi.org/10.1016/j.ab.2011.11.031

2 X. Yang, J. Xu, X. Tang, H. Liu and D. Tian, Chem. Commun., 46, 3107 (2010), https://doi.org/10.1039/C002137G

3 S. Zhan, Y. Wu, Y. Luo, L. Liu, L. He et al., Anal. Biochem., $\quad 462, \quad 19 \quad$ (2014), https://doi.org/10.1016/j.ab.2014.01.010
4 L. Pujol, D. Evrard, K. Groenen-Serrano, M. Freyssinier, A. Ruffien-Ciszak et al., Front. Chem., 2, 1 (2014), https://doi.org/10.3389/fchem.2014.00019

5 E. R. E. Mojica, A. B. Tocino, J. R. L. Micor and C. C. Deocaris, Philipp. J. Sci., 134, 51 (2005), http://philjournalsci.dost.gov.ph/images/pdf/pjs_pdf/vo 1134no1/PDFs/a_feather_trode_sensor_for_detecting_1 ead_ions.pdf

6 T. Agusa, T. Kunito, K. Ramu, C. Chamnan, P. T. K. Trang et al., Biol. Trace Elem. Res., 17, 413 (2006), https://doi.org/10.11299/brte.17.413

7 S. Z. Mohammadi, D. Afzali and D. Pourtalebi, Cent. Eur. J. Chem., 8, 662 (2010), https://doi.org/10.2478/s11532-010-0029-8

8 G. R. de Castro, I. L. de Alcântara, P. dos Santos Roldan, D. de Fatima Bozano, P. de M. Padilha et al., Mater. Res., 7, 329 (2004), https://doi.org/10.1590/S1516-14392004000200018

9 H. P. Mhaske, V. V. Vaidya, S. Shailajan, G. Singh and K. M. Dalvi, Nat. Environ. Pollut. Tech., 5, 389 (2006),

https://scholar.google.com/scholar?hl=en\&as_sdt=0,5 \&cluster $=2699688812679850959$

${ }^{10}$ Y. Xu, J. Zhou, G. Wang, J. Zhou and G. Tao, Anal. Chim. Acta, 584, 204 (2007), https://doi.org/10.1016/j.aca.2006.11.014

11 M. Kaneko and D. Wöhrle, in "Electronic Applications", Springer, Berlin, 1988, pp. 141-228, https://doi.org/10.1007/BFb0025906

12 J. Wang and P. Tuzhi, Anal. Chem., 58, 3257 (1986), https://doi.org/10.1021/ac00127a076

13 A. Maines, A. Cambiaso, L. Delfino, G. Verreschi, I. Christie et al., Anal. Commun., 33, 27 (1996), https://doi.org/10.1039/AC9963300027

14 D. W. M. Arrigan, Analyst, 119, 1953 (1994), https://doi.org/10.1039/AN9941901953

15 X. Li, J. Liu, X. Ji, J. Jiang, R. Ding et al., Sensor. Actuat. B-Chem., 147, $241 \quad$ (2010), https://doi.org/10.1016/j.snb.2010.03.018 
16 F. Meng, W. Shi, Y. Sun, X. Zhu, G. Wu et al., Biosens. Bioelectron., 42, 141 (2013), https://doi.org/10.1016/j.bios.2012.10.051

17 S. A. Khayyat, S. G. Ansari and A. Umar, J. Nanosci. Nanotechnol., 14, $3569 \quad$ (2014), https://doi.org/10.1166/jnn.2014.7918

18 S. Park, H. Boo and T. D. Chung, Anal. Chim. Acta, 556, $46 \quad$ (2006), https://doi.org/10.1016/j.aca.2005.05.080

19 S. B. Khan, S. A. Khan, H. M. Marwani, E. M. Bakhsh, Y. Anwar et al., RSC Adv., 6, 110077 (2016), https://doi.org/10.1039/C6RA21626A

20 K. Akhtar, H. M. Marwani, J. Seo, E. M. Bakhsh, D. Kim et al., Polym. Compos., 38, 2106 (2017), https://doi.org/10.1002/pc.23785

21 E. Y. Danish, H. M. Marwani, M. A. Alhazmi, S. B. Khan, E. M. Bakhsh et al., Bull. Mater. Sci., 41, 47 (2018), https://doi.org/10.1007/s12034-018-1569-3

22 S. A. Khan, N. Khan, U. Irumd, A. Farooq, A. M. Asiri et al., Int. J. Biol. Macromol., 153, 806 (2020), https://doi.org/10.1016/j.ijbiomac.2020.03.013

23 E. M. Bakhsh, S. A. Khan, H. M. Marwani, E. Y. Danish, A. M. Asiri et al., Int. J. Biol. Macromol., 107, 668

(2018),

https://doi.org/10.1016/j.ijbiomac.2017.09.034

24 H. M. Marwani, E. Y. Danish, M. A. Alhazmi, S. B. Khan, E. M. Bakhsh et al., Sep. Sci. Technol., 53, 887 https://doi.org/10.1080/01496395.2017.1405982

25 F. Ali, S. B. Khan, T. Kamal, K. A. Alamry, E. M. Bakhsh et al., Carbohyd. Polym., 192, 217 (2018), https://doi.org/10.1016/j.carbpol.2018.03.029

26 E. M. Bakhsh, F. Ali, S. B. Khan, H. M. Marwani, E. Y. Danish et al., Int. J. Biol. Macromol., 131, 666 (2019), https://doi.org/10.1016/j.ijbiomac.2019.03.095

27 S. B. Khan, K. Akhtar, E. M. Bakhsh and A. M. Asiri, Appl. Surf. Sci., 492, 726 (2019), https://doi.org/10.1016/j.apsusc.2019.06.205

28 S. B. Khan, F. Ali and K. Akhtar, Carbohyd. Polym., 207, 650 (2019) https://doi.org/10.1016/j.carbpol.2018.12.032

29 A. M. Asiri, K. Akhtar and S. B. Khan, Ceram. Int., 45, 13340

(2019),

https://doi.org/10.1016/j.ceramint.2019.04.028

30 F. El-Ashhab, L. Sheha, M. Abdalkhalek and H. A. Khalaf, J. Assoc. Arab Univ. Basic Appl. Sci., 14, 46 (2013), https://doi.org/10.1016/j.jaubas.2012.12.001

31 S. Fischer, K. Thummler, B. Volkert, K. Hettrich, I. Schmidt et al., Macromol. Symp., 262, 89 (2008), https://doi.org/10.1002/masy.200850210

32 C. Varsha, S. K. Bajpai and C. Navin, Int. Food Res. J., 17, 623 (2010), Corpus ID: 199423472

33 F. J. Rodríguez, M. J. Galotto, A. Guarda and J. E. Bruna, J. Food Eng., 110, 262 (2012), https://doi.org/10.1016/j.jfoodeng.2011.05.004

34 W. K. Son, J. H. Youk and W. H. Park, Carbohyd. Polym., $\quad$ 65, $430 \quad$ (2006), https://doi.org/10.1016/j.carbpol.2006.01.037
35 J. Cao, X. Ma, A. Yang and W. Xu, Polym. Polym. Compos., $\quad 14, \quad 65 \quad$ (2006), https://doi.org/10.1177\%2F096739110601400106

36 W. Chen, Y. Su, L. Zhang, Q. Shi, J. Peng et al., J. Membr. $\quad$ Sci., $\quad 348, \quad 75 \quad$ (2010), https://doi.org/10.1016/j.memsci.2009.10.042

37 M. Naghsh, M. Sadeghi, A. Moheb, M. P. Chenar and M. Mohagheghian, J. Membr. Sci., 423-424, 97 (2012), https://doi.org/10.1016/j.memsci.2012.07.032

38 W. G. Kim, J. S. Lee, D. G. Bucknall, W. J. Koros and S. Nair, J. Membr. Sci., 441, 129 (2013), https://doi.org/10.1016/j.memsci.2013.03.044

39 R. Abedini, S. M. Mousavi and R. Aminzadeh, Desalination, 277, 40 (2011), https://doi.org/10.1016/j.desal.2011.03.089

40 A. Gholami, A. R. Moghadassi, S. M. Hosseini, S. Shabani and F. Gholami, J. Ind. Eng. Chem., 20, 1517 (2014), https://doi.org/10.1016/j.jiec.2013.07.041

41 V. K. Gupta, D. Pathania, P. Singh, B. S. Rathore and P. Chauhan, Carbohyd. Polym., 95, 434 (2013), https://doi.org/10.1016/j.carbpol.2013.02.045

42 L. Wu, M. Shamsuzzoha and S. M. C. Ritchie, J. Nanopart. Res., 7, $469 \quad$ (2005), https://doi.org/10.1007/s11051-005-4271-5

${ }^{43}$ L. Wu and S. M. C. Ritchie, Chemosphere, 63, 285 (2006), https://doi.org/10.1016/j.chemosphere.2005.07.021

44 L. Wu and S. M. C. Ritchie, Environ. Prog., 27, 218 (2008), https://doi.org/10.1002/ep.10277

45 L. Wu, J. Chen, D. Du and H. Ju, Electrochim. Acta, 51, 1208 (2006), https://doi.org/10.1016/j.electacta.2005.06.011

${ }^{46}$ X. Ren, D. Chen, X. Meng, F. Tang, A. Du et al.,

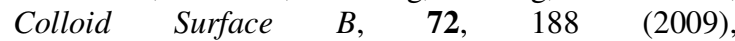
https://doi.org/10.1016/j.colsurfb.2009.04.003

47 E. Hendrick, M. Frey, E. Herz and U. Wiesner, $J$. Eng. Fiber. Fabr., 5, $21 \quad$ (2010), https://doi.org/10.1177\%2F155892501000500103

48 S. B. Khan, M. M. Rahman, K. Akhtar, A. M. Asiri, K. A. Alamry et al., Int. J. Electrochem. Sci., 7, 10965

http://www.electrochemsci.org/list12.htm\#issue7

${ }^{49}$ S. Liu, J. Tian, L. Wang, X. Qin, Y. Zhang et al., Catal. Sci. Technol., 2, $813 \quad$ (2012), https://doi.org/10.1039/C2CY00453D

50 A. M. Asiri, S. B. Khan, K. A. Alamry, H. M. Marwani and M. M. Rahman, Appl. Surf. Sci., 270, 539 (2013), https://doi.org/10.1016/j.apsusc.2013.01.083

51 S. B. Khan, K. A. Alamry, H. M. Marwani, A. M. Asiri and M. M. Rahman, Compos. Part B-Eng., 50, 253

(2013),

https://doi.org/10.1016/j.compositesb.2013.02.009

52 A. P. Moura, L. S. Cavalcante, J. C. Sczancoski, D. G. Stroppa, E. C. Paris et al., Adv. Powder Technol., 21, 197

(2010), https://doi.org/10.1016/j.apt.2009.11.007

53 X. Wang, C. Hu, H. Liu, G. Du, X. He et al., Sensor. Actuat. B-Chem., 144, 20 (2010), https://doi.org/10.1016/j.snb.2009.09.067 
KHALID A. ALAMRY et al.

54 M. de C. C. Lucena, A. E. V. de Alencar, S. E. Mazzeto and S. d. A. Soares, Polym. Degrad. Stabil., 80, 149 (2003), https://doi.org/10.1016/S01413910(02)00396-8

55 M. Ali, M. Zafar, T. Jamil and M. T. Z. Butt, Desalination, $\quad 270, \quad 98 \quad$ (2011), https://doi.org/10.1016/j.desal.2010.11.027

56 P. K. Chatterjee and C. M. Conrad, J. Polym. Sci. Pol. Chem., 6, $3217 \quad$ (1968), https://doi.org/10.1002/pol.1968.150061202

57 A. A. Hanna, A. H. Basta, H. El-Saied and I. F. Abadir, Polym. Degrad., 63, 293 (1999), https://doi.org/10.1016/S0141-3910(98)00108-6

58 T. L. Hai, L. C. Hung, T. T. B. Phuong, B. T. T. Ha, B. S. Nguyen et al., Microchem. J., 153, 104456 (2020), https://doi.org/10.1016/j.microc.2019.104456

59 D. F. Katowah, M. A. Hussein, M. M. Alam, M. A. Gabal, T. R. Sobahi et al., Chem. Select., 4, 10609 (2019), https://doi.org/10.1002/slct.201902714

60 A. A. P. Khan, A. Khan, A. M. Asiri, M. M. Alam, M. M. Rahman et al., Int. J. Environ. Sci. Technol., 16, 8461 (2019), https://doi.org/10.1007/s13762-019$\underline{02447-8}$
61 S. B. Khan, M. M. Rahman, K. Akhtar, A. M. Asiri and M. A. Rub, PLoS ONE, 9, 85290 (2014), https://dx.doi.org/10.1371\%2Fjournal.pone.0085290

62 S. B. Khan, M. M. Rahman, A. M. Asiri, S. A. B. Asif, S. A. S. Al-Qarni et al., Phys. E, Low Dimens. Syst. $\quad$ Nanostruct., $\quad$ 62, $21 \quad$ (2014), https://doi.org/10.1016/j.physe.2014.04.007

63 S. B. Khan, H. M. Marwani, A. M. Asiri and E. M. Bakhsh, Desalin. Water Treat., 57, 19311 (2016), https://doi.org/10.1080/19443994.2015.1109560

${ }^{64}$ H. M. Marwani, M. U. Lodhi, S. B. Khan and A. M. Asiri, J. Taiwan Inst. Chem. E, 51, 34 (2015), https://doi.org/10.1016/j.jtice.2015.01.018

${ }_{65}$ M. M. Rahman, S. B. Khan, H. M. Marwani, A. M. Asiri, K. A. Alamry et al., J. Ind. Eng. Chem., 20, 1071 (2014), https://doi.org/10.1016/j.jiec.2013.06.044 66 D. Ouyang, Y. Zhuo L. Hu, Q. Zeng, Y. Hu et al., Minerals, 9, 291 (2019), https://doi.org/10.3390/min9050291 